\title{
一般演題〈研究〉生と性の教育
}

\section{1 助産婦による「命の誕生に関する授業」の評価}

\author{
日本助産婦会東京都支部「助産婦が小学生に伝える命の梴生モテル事業」評価班 \\ ○斎 藤 美貴 有森直子片 桐 麻州美 \\ 清 水理 花堀 内成子
}

\section{I 粕 言}

今日、性教育へのアプローチは、その内容やリソースについて様々な試みが行われている。助 産婦は日々命の誕生に携わっており、生きた言葉でその体験を伝えることに適したリソース・パー ソンといえる。今回、助産婦が職能団体として学校と連携を図り、小学生を対象に「命の誕生に 関する授業」を企画から実施・評価まで行った。本研究の目的は、対象児童・保護者の質問紙調 査の結果に基き授業の評価を行うことである。

\section{II 方 法}

対象は、都内の小学 5 年生 3 学級（90人）と参加可能な保護者とした。実施にあたり、小学 校教諭及び性教育に揞わる有識者・涉外担当助産婦による通算 13 回の事前会議を行い、授業内 容·評価方法等に関する検討を重ねた。又、本事業の目的である「小学生が家庭で生命誕生の仕組 みや命の尊さについて、自分の感じたことや考えたことを自由に語れるようになること」への取 り組として、保護者が命に対して再認識し児童と体験を共有する場を設けるため、開催日を授業 参锤日とし 1 時間の授業（於体育館）を開催した。授業の具体的な目標として、「目標 1 : 生命誔 生のプロセスを知り、一つ一つの生命が唯一無二であることを理解できる」「目標 2 : 家族や周囲 の人達に祝福され生まれる命の誕生に気付き、その絆を確かめることができる」「目標 $3:$ 命の意 味について家庭で話し合うきっかけができる」「目標 4 : 自分自身の命の意味について考え、かけ がえのない存在としての自己に気付くことができる」「目標 5 : 命はここに在るだけで価值がある ことに気付き、他者の命を大切にする意味に気付くことができる」と定めた。評価方法は質問紙 法を用いた。授業終了後に学級担任を通じて教室で配布し、その場で記入・回収（保護者は児童か ら手渡し、後日、児童を通じて担任が回収）した。質問紙の内容は、授業に参加し 1 よかったこ と、2 いやだったこと、3 変化したこと、4 もっと知りたいこと、5 感想 (保護者のみ、6 家 庭で話し合った内容）である。分析方法は、文脈に基く内容分析を行った。

\section{III 結 果}

授業後の質問紙調査に対する児童 80 名（回収率 $82 \%$ )・保護者 18 名の回答について、文脈に よる内容分析（記述数 : 児童 234 ・保護者 98）を行った。その結果、児童に関しては「誕生に至 る過程が理解できた」「出産の苦労を知り怖くなった」「命の誕生は祝福に包まれていると気付い 
た」「自分の命の意味を知ることができた」等 22 項目がカテゴリー化された。そして、どの程度 自分自身に引き寄せて理解しているかにより、「レベル 1 :生命誔生に関連する客稓的事実の理解」 「レベル 2 :命のリアリティに対する不安や気持ちの悪さ」「レベル 3 :周囲の人とのつながりの中 に在る命への気付き」「レベル 4 :自分自身の命の意味に対する気付き」「レベル 5 : 他者の命の尊 重」に分類した。保護者の回答からは「命の大切さを認識した」「我が子のかけがえのなさを再認 識した」「出産・育児体験を振り返った」をはじめとする 24 項目が抽出され、生徒と同様にそれ らを 5 つに分類した。次に、学習目標 5 項目に沿って上記を分類し達成度を評価した。目標 1 に 関して 111 件、目標 $2 て ゙ は 58$ 件、目標 3 は 23 件（保菨者のみ）の記述数であった。一方、目標 4 では 38 件、目標 5 は 2 件の記述数に留まった。また記述された内容の全体的特徽として「小学 5 年生の成熟度の幅広さ」「命のリアリティに対するネガティプな反応「模擬体験のインパクト の大きさ」がみられた。

\section{IV 考 察}

上記の結果から、目標 $1 \cdot 2 \cdot 3$ に関しては学習目標をほほ達成できたと判断した。また、目標 4 . 5 については、前述の 3 項目に比して達成度がやや低いと判断した。

レベル 1 から 4 に至るまで、児童の理解の深さは様々である。成熟度に応じた多様な教材開発 が重要であり、特に「模稀体験のインパクトの大きさ」の活用が効果的であった。また、レディ ネスが整い自分自身の性・生について考え始めた時に個別的な対応ができるよう、学校との連携 を通じて継続性を保証する必要がある。特に、陣痛の痛み等「生命のリアリティに不安」を感じ た児童や複雑な家族噮境に置かれた子どもに対する、授業後のフォローアップが大切と考える。

本事業の目的は、「小学生が家庭で生命誕生の仕組みや命の尊さについて、自分の感じたことや 考えたことを自由に語れるようになること」であるが、その達成には、性と生に関する保護者の 受け止め方が何より重要である。授業参加を通じて保謡者が命の尊さを再認識し、自らの感動や 体験から発せられる「生きた言葉」を用いて子どもと語り合う禁境を整える上で、一定の効果が 得られたと考える。今後、授業に参加できない保護者の体験の共有化を図る工夫も必要であろう。

「一人一人の命のかけがえのなさ」を尊重し他者への労りを表見できる原点は、自分自身の存 在価值や愛情に対する信頼に在る。従って、児童が自らの誕生や成長過程に目を向け、要情に包 まれてきた歳月を辿ることで自身のかけがえのなさを実感し、他者の命の尊重へつながる道筋を 示す役割を果たせたと考える。客観的事実に関する「三人称の理解」を基盤としながらも、他者 との関倸性を重視した「二人称の理解」や、自分自身への問いかけである「一人称の理解」を深 められるような効果的な取り組みを、今後、更に開発·発展させてゆく必要があると考える。

\section{$\mathrm{V}$ 結 論}

授業終了後に、児童・保護者を対象に質問紙調查を実施した。その回答をもとに学習目標 $\mathbf{5}$ 項 目の達成度を評価した結果、概敉目標を達成したと判断された。具体的には、3 項目について十 分に目標が達成され、 2 項目はやや達成度が低かった。「自分自身の命に引き奇せた理解」や、他 者の命のかけがえなさへの気付き」に焦点を当てた授業内容・教材開発を進めることにより、今 後、更に目標達成度を高められるものと期待される。 


\title{
一般演題〈研究〉生と性の教育
}

\section{2 \\ 看護学生・助産婦学生による性教育出前授業 一中学 3 年生へ総合的学習としての性教育一}

\author{
東北大学医療技術短期大学部 ○小山田 信 子 \\ 山梨医科大学医学部看護学科 柳 原 真知子
}

I 緒言 学校の性教育が、地域の助産婦との交流により試みられ、その成果が報告されてきて いる。性教育を充実させていくには子どもの発達段階を考虑しながら進めていくことも大切 である。小学生は性知識の情報源のほとんどを親としているが、中学生以上になると雑誌、 ビデオそして友人が大半を占め、大人から性知嬂を得ることを忌澼する傾向が見られる。欧 米では若者の性教育に、年齢の近い者が携わり、ピアカウンセリングの効果が期待されている。

今回、S市立T中学校で総合的学習の一貫として行われた性教育に看䚺学生・助産婦学生が、 T·T(team teaching)として参加した。この新たな試みは、中学生からの評価も高く、また学 生自身も多くの学びをすることができた。中学生と学生へのアンケート調査の結果から今回 の性教育出前授業の効果や学生の学びを検証し考察した。

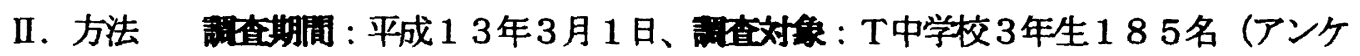
一ト回収数 174 名)、看護学生 9 名、助産婦学生 5 名(アンケート回収 10 名)、担任の教諭 5 名 (回収 3 名) 誏査方法 : 中学生 : 半構成的質問紙法、看護学生・助産婦学生 : 自由記载、 分析力法 : 内容分析及び KJ 法を参考に分類、

III. 結果・考察 1. 中学生からの評価

1）授業で「関心の持てたこと」については、一番多かったのは避妊や避妊用具(42.4\%)で あった。これは、授業目標の「1 避妊の意義が理解できる、2避妊の責任が理解できる、 3 避妊方法や注意点が理解できる」であり、避妊を重点に授業展開されたことの効果と 推察できる。

2）「避妊について」の子どもたちの考えでは、避妊の必要を述べたもの 47.4\%、大事あるい は大切としたもの $14.0 \%$ 二人で話し合うは 7.0\%であった。少数ではあるが、わからな い5.3\%、、けないこと 4.1\%であった。避妊は、性の価値観などとも深く関連しており、 強制すべきことではない。少数とは言え否定的な意見を持った生徒に対して、その子ど もの意見を尊重するよう、授業の工夫が必要である。

3）看護学生・助産婦学生について、、表 1 のごとく、多くの生徒は肯定的に評価していた。 
学生による性教育は、親近感を強め、授業への生徒の参加度を高めていたと思われる。

4）グループ・ワークについては、表 2 のごとく、多くは满足していたが、 少数のグループでは、グループダイナミ ックスが上手く機能せず、充実感が持て なかった。今後、グルーフ構成について 改善・工夫していく必要がある。

しかし、上手く機能したグループは、 学生との関係のみならず、生徒同士の ピアカウセリング効果もあり、充実感 を得ていた。

2. 看護学生・助産婦学生の評価

今回の性教育は、健康教育の援助とし て位置付け展開された。実施後の学生 のアンケートからの意見として,主要な 内容は(1)グループ・ワークの編成の問 題、(2)グループ・ワークの進め方、(3)子 どもの個人差について分類され、授業展 開における内省的な振り返りと解决につ いての具体策が示されていた。

IV・結論 学生による性教育は、生徒に 年龄が近いことによる仲間としての接近 感を持ち、抵抗感なく授業の内容が受け 入れられたようである。また、学生自身 健康教育として設定された指導について、 クリティカルな観点から自己の実践を振 り返ることができた。世界的な流れとし て若者の性教育には若者が担当すること が推桨されてきている。今後、性教育が 学生により展開されるよう大学のカリキ ュラムの改善や開発が必要である。 文献

1. 松本清一他、性の自己決定能力を育 てるピアカウンセリング、小学䗆, 1999

2. 有輻格他、中学校の総合的学習、

ぎょうせい, 1999
表 1 看護学生・助産婦学生について

\begin{tabular}{|c|c|c|}
\hline & 有协回答数 1 & $8(\%)$ \\
\hline カテコリー & 内 & 菬果 \\
\hline かかりやナかった & $\begin{array}{l}\text { - とてもかかりやなくてよかったでナ } \\
\text { · かかりやナい娘内賽てした }\end{array}$ & $47(28.0)$ \\
\hline $\begin{array}{l}\text { ためになった・いい } \\
\text { 策た゚った }\end{array}$ & 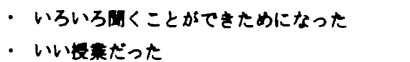 & $30(17.9)$ \\
\hline 米しいおるしろい & $\begin{array}{l}\text { · とてもたのしくできてよかった } \\
\cdot \text { · とてもおししろかった }\end{array}$ & $29(17.3)$ \\
\hline 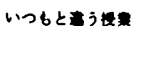 & 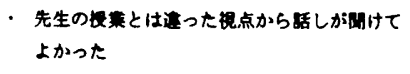 & $16(9.6)$ \\
\hline 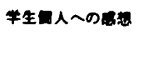 & 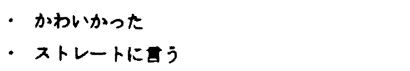 & $15(8.9)$ \\
\hline F生へに買近昆 & 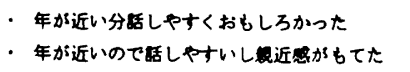 & $11(6.5)$ \\
\hline & 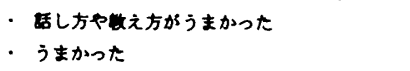 & $3(1.8)$ \\
\hline 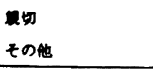 & ・钬だった & $\begin{array}{l}2(1.2) \\
15(8.9) \\
\end{array}$ \\
\hline
\end{tabular}

表2グルプ・ワークについて

\begin{tabular}{|c|c|c|}
\hline カテニリー & 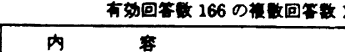 & $79(\%)$ \\
\hline $\begin{array}{l}\text { おठしろかった・果しかっ } \\
\text { た }\end{array}$ & 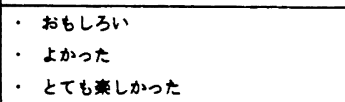 & $57(31.8)$ \\
\hline 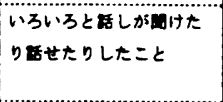 & 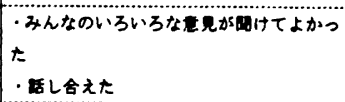 & $35(19.6)$ \\
\hline 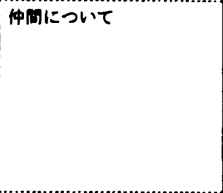 & 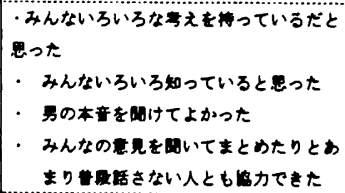 & $21(11.7)$ \\
\hline 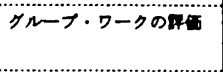 & 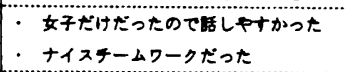 & $16(8.9)$ \\
\hline クループ・ワークの间这 & 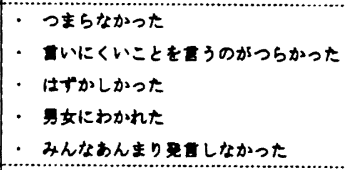 & $15(8.4)$ \\
\hline 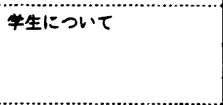 & 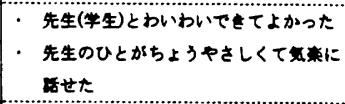 & $14(7.8)$ \\
\hline $\begin{array}{l}\text { クルーフ・ワークルスにつ } \\
\text { いてのター }\end{array}$ & 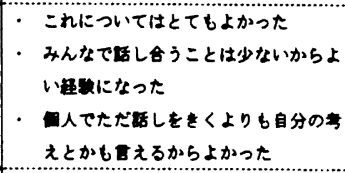 & $6(3.4)$ \\
\hline 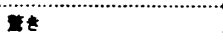 & 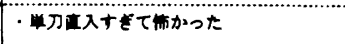 & $2(1.1)$ \\
\hline モの他 & & $13(7.3)$ \\
\hline
\end{tabular}




\section{一般演題〈研究〉生と性の教育}

\section{3}

\section{高校生を対象とした性教育の現状と問題点}

佐賀県看護協会助産婦職能委員会

○服 部 佳代子大島玲子 溝 口 明美

内 野 秋子北 原 真理子

\section{I 緒 言}

1992 年に改定された学習指導要綱により、「性」に関する教育は養護教諭のみならず学級担任 も関わる事となった。しかしながら、情報の汇監と言われる現代社会で学生が得ている「性」に 関する情報は多種多様化しており、教育者であっても具体的な教育内容については多くの問題を 抱えている ${ }^{1}$ 。ここような現状の中、助産婦による性教育が学校教育の中で取り入れられ 2)、わ れわれも高校生を対象とした学校での性教育にかかわる機会があった。今回、われわれが行った 性教育が、学生の「性的自己決定力」を身に付けるために役立つ教育内容であったかの検討を行 い、若干の知見が得られたので報告する。

\section{II 研究方法}

$\mathrm{S}$ 県 T高等学校の生徒 895 名（男子 850 名、女子 45 名）を対象として性教育実施した（2001 年 7 月)。その前後で「性的自己決定力」の構成要素である予知力および交渉力に関するアンケー 卜調査を行った。実施した性教育の内容は、VTR（生命の成り立ち、誕生、いのちの尊さ）、講 話（性行動の目的、性行為のあり方、性行動の結果、性行為感染症、自己肯定意識）である。

尚、アンケート記載は無記名とし、アンケート主旨の説明を行い、承諾の上アンケート調査を 行った。

\section{III 結果 （表 $1 \cdot$ 表 $2 \cdot$ 表 3 参照）}

多肢選択法の結果は表 1 ・表 2 に示すとおりであり、自由記載法の結果は表 3 に示すとおりで ある。 表 2 性教育実施前後の交涉力の変化（\%)

表 1 性教育実施前後の予知力の変化（\%)

\begin{tabular}{|c|c|c|c|c|c|}
\hline 内容 & $\begin{array}{c}\text { 性教育実施 } \\
\text { 前後 }\end{array}$ & (1) & (2) & (3) & (4) \\
\hline \multirow{2}{*}{$\begin{array}{l}\text { 避娃について } \\
\text { 知っています } \\
\text { か }\end{array}$} & 前 & 20 & 68 & 7 & 4 \\
\hline & 後 & 27 & 66 & 5 & 2 \\
\hline \multirow[t]{2}{*}{$\begin{array}{l}\text { 人工妊娠中絶 } \\
\text { につて知っ } \\
\text { ていますか. }\end{array}$} & 前 & 17 & 59 & 19 & 5 \\
\hline & 後 & 27 & 67 & 4 & 2 \\
\hline \multirow{2}{*}{$\begin{array}{l}\text { エイズをとの } \\
\text { 性行為感染症 } \\
\text { について知っ } \\
\text { ていますか }\end{array}$} & 前 & 37 & 56 & 6 & 1 \\
\hline & 後 & 35 & 61 & 2 & 2 \\
\hline
\end{tabular}

(1)よく知っている(2)大体知っている(3)知らない(4)意味がわからない

\begin{tabular}{|c|c|c|c|c|c|}
\hline 内容 & $\begin{array}{c}\text { 性教育実施 } \\
\text { 前後 }\end{array}$ & (1) & (2) & (3) & (4) \\
\hline \hline $\begin{array}{c}\text { セックスする前に避 } \\
\text { 妊のことについて相 } \\
\text { 手の人と話し合うこ } \\
\text { とができますか }\end{array}$ & 前 & 26 & 52 & 17 & 5 \\
\cline { 2 - 7 } & 後 & 43 & 4 & 50 & 3 \\
$\begin{array}{c}\text { 性行為感染症予防の } \\
\text { ため、さントームを } \\
\text { 使うことを相手の人 } \\
\text { と話し合うことが出 } \\
\text { 来ますか }\end{array}$ & 前 & 38 & 5 & 53 & 4 \\
\hline
\end{tabular}

(1)できる(2)できない(3)その時になってみないと(4)意味がわからない 
表 3 性教育実施後の自由記載内容（一部抜粋）

\begin{tabular}{|c|c|c|}
\hline $\begin{array}{l}\text { 分 } \\
\text { 類 }\end{array}$ & & 容 \\
\hline \multirow[t]{3}{*}{ 力 } & $\begin{array}{l}\text { 性行為の目的 } \\
\text { 性行為の } \\
\text { あり方 }\end{array}$ & 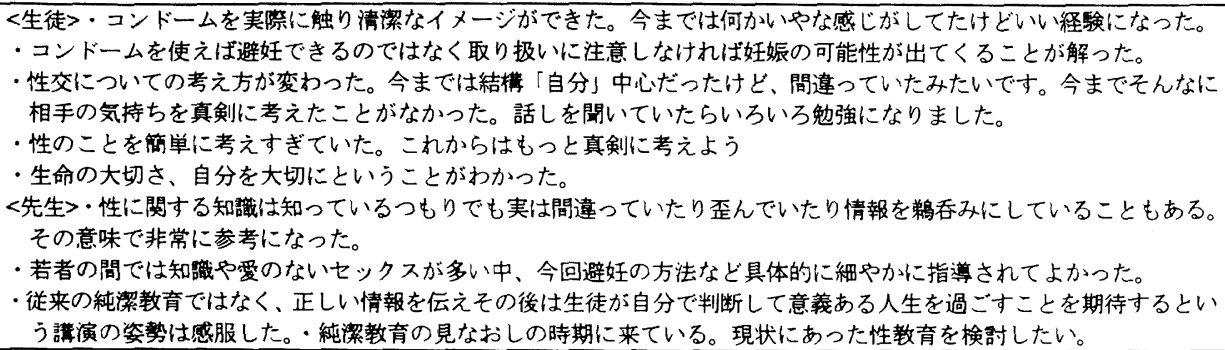 \\
\hline & 性行動の結果 & $\begin{array}{l}\text { <生徒>・人工娃娠中絶は危ないだけでなく、女の人に与える精神的なダメージもあるんだなあと思った。 } \\
\text { ·性を一つの物事として考えるのではなく、そこから生まれてくる妊娠中絶、性感染症について学んでいく、お互いに } \\
\text { 理解していくことが大切。 } \\
\text { ·妊娠したくないなら避娃をちゃんとすることが重要だと。 }\end{array}$ \\
\hline & STD & 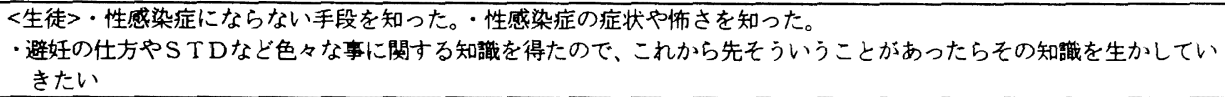 \\
\hline \multirow[t]{2}{*}{ 力 } & $\begin{array}{l}\text { 性行為の目的 } \\
\text { 性行為の } \\
\text { あり方 }\end{array}$ & 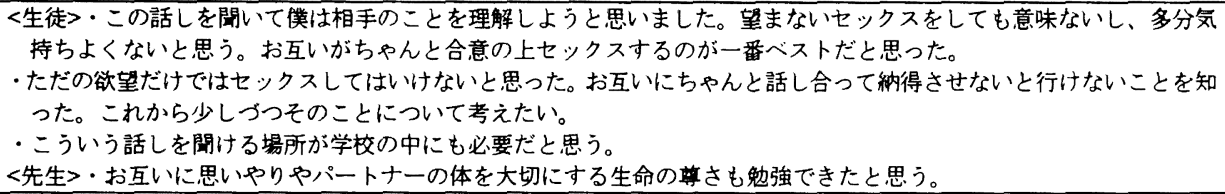 \\
\hline & 性行動の結果 & $\begin{array}{l}\text { <生徒>・男から無理やり性行為をやられた女の人の話を闑いて、その女の人の人生がだいなしになってしまうのがとて } \\
\text { も悲しいことだと思った。 } \\
\text { <先生>・お互いに思いやりやパートナーの体を大切にする生命の草さも勉強できたと思う。 }\end{array}$ \\
\hline
\end{tabular}

IV考察

今回行ったアンケート調査を検討した結果、ほとんどの学生（約 $90 \%$ ）が避妊、中絶および

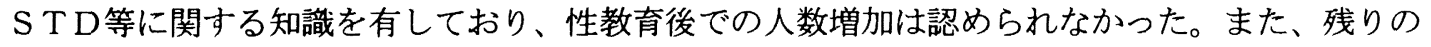
約 $10 \%$ 学生に対しては、避妊、中絶およびS T D等に関する知識を与えることができなかっ た。現在、性に関する情報が T Vや雑誌等で容易に得られる状況であり、ほとんどの学生達はす でに性交渉に関するある程度の知識は得ているものと思われる。しかしながら、自由記載のアン ケートの結果、性交渉に関する情報は得ているものの、その自分の得ている知識については懐疑 的であり、自信を得るまでには至っていない。また、性教育実施後であっても避妊方法について 相手と交涉を行う事ができない学生が半数以上認められた。よって、従来の方法で性教育を行っ た場合、学生の知識に対する自信 (再認識) は与える事ができたとしても、相手と避妊の交涉を 行う必要性までの認識は与えることはできない。また、性に関する知識が得られなかった $10 \%$ の学生に対してアドバイスを与える機会が失われてしまう事になりかねない。

これらの事より、性教育を行う前に、何について学生が知りたいのかを十分把握し、養護教諭 および学級担任を交えて実施する性教育の内容検討を行っていく必要があると思われた。さらに 従来の性教育の内容を再検討し、小グループでのカウンセリング的な方法を取り入れた性教育の 検討の必要性があると思われた。

\section{V文献}

1）村瀬幸治：学校性教育のこれからの課題は何か 特集／生命倫理から性を問う 産婦人科の世界 Vol.51 1999

2）鈴木せい子他：特集 助産婦のになう性教育 助産婦雑誌 V o $1.55 \quad \mathrm{~N}$ o. 82001 


\section{一般演題〈研究〉生と性の教育}

54

\section{現代の人工妊娠中絶をめぐる意識 一未婚の有職女性への意識調査一}

$\begin{array}{rrrr}\text { 山梨医科大学 O柳 } & \text { 原 } & \text { 真知子 } \\ " & \text { 西 } & \text { 脇 } & \text { 美 春 } \\ \text { 北海道大学 } & \text { 岩 } & \text { 田 } \text { 銀 子 }\end{array}$

\section{I. 緒言}

リプロダクティブ・ヘルス/ライツが、北京会議で提唱され、女性の性と生殖への選択的な権利が 諗められるようになってきた。生殖の選択には、最終手段として人工妊娠中絶(以下中絶とする)も 含まれるだろう。しかし、中絶は両刃の刃であり、望まない妊張からの自由を得ると共に、身体的心 理的侵襲を残すことがある。

わが国において明治時代に施行された随胎罪は中絶を犯罪とし、中絶した女性を犯罪者として 断罪してきた。その時代、富国強兵のために中絶を犯罪として刻印することにより、中絶を抑制する 効果を得ようとしてきた。戦後は人口抑制手段が取られ、優性保護法のもと中絶の届出総数は昭和 30 年に 117 万となっていた。このような歴史的変遷の摇れ動きの中で今日、女性たちは中絶をど のように考えているだろうか。科学の発達した時代においても、水子供養が盛んであるという現象 は、中絶への罪悪感なのか失った子どもへの敬虔な思いなのだろうか。

これまで、助産婦は生む性を中心に関わり、生まない性や生めない性への援助が希薄であった。 そこで中絶という生まない性への援助の方向性を模索するため、未婚の有職女性を対象に調査を おこなった。末婚の女性を対象にしたのは、平成 7 年以降未婚女性の中絶数が既婚女性の中絶 数を上回ったこど、また未婚女性の性交経験者が増加してきていることなどによる。

II. 方法 調查期間:平成 13 年7月 1 日か58月31日。調查対象:東京、山梨、福岡、宮崎、沖縄 県に在住する会社及び官公庁に勤務する未婚の女性. 配布数 315 部、回収数 161 部(回収率 51.1\%)。調查方法:質問紙法によるアンケート調査。質問の内容項目は中絶、水子の霊について で、回答はリカート法を参考に作成。回収は個別又は郵送回収。密封回収。分析方法:エクセルで 集計分析した。倫理的兒慮:研究目的以外に使用しないこと、データーは個人の回答が公にされ ないことを伝え、調査の主旨に賛同した者にのみ回答を求めた。

III. 結果 1. 対象者の属性:年跲の平均は 25. 3 歳。2. 中絶について:1) 中絶は許されるに対し て、有効回答数153で非常にそう思う4.6\%、少しそう思う45.1\%、あまり思わない $17.6 \%$ 、まったく 思わない 13.1\%、わからない 19.6\%であった。2) 中絶は女性の体によくないに対して、有効回答 数157で非常にそう思う 83.46\%、少しそう思う 14.7\%、あまり思わない 0\%、まったく思わない 0\%、 わからない $1.9 \%$ あっあた。3)認められる中絶の理由としては、複数回答で回答数は482であった。 


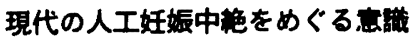

最も多い理由としては、表 1 ごとくレイプ、病気、貧困などが上位を占めていた。 4)中絶は女性の権利に対して、有効回答数 表 1 認められる中絶の理由 $\mathrm{N}=477$ (重複回答) 150 で、非常にそう思う $12 \%$ 、少しそう思 う36\%、あまり思わない $9.3 \%$ 、まったく 思わない $13.3 \%$ 、わからな $29.3 \%$ で あった。5) 中絶をしたら罪悪感を持つに 対して、有効回答数 151 で、非常にそう 思う66\%、少しそう思う22\%、あまり思わ ない 1\%、まったく思わない0\%、わから ない $11 \%$ であった。2. 水子の霊は存在 するに対して、有効回答数152で非常に そう思う 15.8\%、少しそう思う $34.2 \%$ 、あ まり思わない 6.6\%、まったく思わない 7.9\%、わからない $35.5 \%$ であった。 3. 障害を持った胎児の中絶は許されるに 対して、非常にそう思う $8.5 \%$ 、少しそう 思う40.8\%、あまり思わない 9.2\%、まっ

\begin{tabular}{|c|c|c|}
\hline 理由 & 項 目, & 人数(\%) \\
\hline 社会的 & レイプ & $129(27.0)$ \\
\hline \multirow[t]{6}{*}{ 理由 } & 希望の妊娠でい & $45 \quad(9.4)$ \\
\hline & 夫による無理やりの奼娠 & $35 \quad(7.3)$ \\
\hline & 不倫 & $30 \quad(6.3)$ \\
\hline & 未婚 & $25 \quad(5.2)$ \\
\hline & 子どもがたくさんいる & $8 \quad(1.7)$ \\
\hline & 仕事がある & $6 \quad(1.3)$ \\
\hline 身体的 & 病気 & 78 (16.4) \\
\hline \multirow[t]{2}{*}{ 理由 } & 高年龄 & $22 \quad(4.6)$ \\
\hline & 若年令 & $20 \quad(4.2)$ \\
\hline 経済的 & 蚠困 & $74(15.5)$ \\
\hline \multirow[t]{2}{*}{ 理由 } & 家が狭い & $1 \quad(0.2)$ \\
\hline & その他 & $4 \quad(0.9)$ \\
\hline
\end{tabular}
たく思わない $7.9 \%$ 、わからない $33.6 \%$ であった。

IV. 考察:有職未婚女性は中絶をどのように考えているかを見たが、中絶を約半数近くの女性が 容認していた。しかし、中絶を容認しても、中絶が女性の身体に良くないと考えていた。中絶への 罪悪感について約 9 割近くの女性が認めていた。

中絶は戦前において犯罪であったが、現代では権利として考える人々も出てきている。調査で権 利と考える女性は半数であった。中絶を権利として容認すべきか否が、今後慎重に検討されなけ ればならない。科学万能と言われる現代において; 水子という非科学的概念が若い女性にどのよう に容認されているかであるが, 約半数近くの女性が存在すると思うと回答していた。今日なお水子 供恙のお寺が繁盛している背景には、水子の霊を否定しきれない女性の存在があるからかもしれ ない。そして、その背景には中絶を、さまさまな理由で認めても罪悪感が残るとする葛藤が存在し ている。中絶する女性への心身のケアが重要である。

障害を持った胎児の中絶について、一般の中絶と同じように容認されていたが、出生前診断技 術の進歩の中で、障害をもった胎児の中絶が問題となる中、同じ視点で考えることはできないだろ う。また、中絶へのケアにおいて受容的な援助が必要である。

V. 結論: 半数の女性が中絶を認め権利と考えていたが、9 割近くの女性が中絶に罪悪感を持 つと考えていた。引用文献 1)木村好秀他人工妊娠中絶実施者に関する社会医学的研究第 1 報，母性衛生 42(2),369,2001 参考文献: 1 . 大津忠男、間引きと水子、農山漁村文化協会、昭和 59 年 2 . 鈴井江三子、人 工妊娠中絶を経䀦した女性の不安の経時的変化、母性衛生 42(2)、2001 3. 荻野美穗 中絶論争とアメ川カ社 会、岩波書店、2001 